\title{
Urban Space and Representation in Literary Study
}

\author{
Long Shi, Qingwei Zhu \\ College of Foreign Languages, Pingdingshan University, Pingdingshan, China \\ Email: longarthur@163.com
}

How to cite this paper: Shi, L. and Zhu, Q.W. (2018) Urban Space and Representation in Literary Study. Open Journal of Social Sciences, 6, 223-229.

https://doi.org/10.4236/jss.2018.69015

Received: August 6, 2018

Accepted: September 16, 2018

Published: September 19, 2018

Copyright $\odot 2018$ by authors and Scientific Research Publishing Inc. This work is licensed under the Creative Commons Attribution International License (CC BY 4.0).

http://creativecommons.org/licenses/by/4.0/

\begin{abstract}
The questions of what a city is and how cities are represented in literary works have occupied the attention of many scholars. When literary works gives urban imaginative reality, and in turn the urban changes promotes the turn of literary texts. It is the textuality that is taken as the constant mutual construction between urban and fiction.
\end{abstract}

\section{Keywords}

Urban Space, Representation, Literary Texts

\section{Urban Space: History and Essence}

Time and space are two dimensions in which human beings exist, as Ernst Cassirer says, "space and time are the framework in which all reality is concerned. We cannot conceive any real thing except under the conditions of space and time" [1]. Far from being separate, time and space form an indivisible whole, that is, time without space or space without time is unimaginable. However, people always attach greater importance to time or space in a certain period, which results in different ways of thinking and different ideas. Theoretical thinking, which focuses on time, treats things in a diachronic and historical dimension, imploring the becoming, evolution, rheology and development to form thinking mode characterized with temporalization and historicization; theoretical thinking, which focuses on space, treats things in a spatial and juxtaposed dimension, emphasizing the synchronicity, presence, and constitution to form thinking mode characterized with specialization. However, time based on history became the prevailing cognitive approach until 20th century, while space is buried under the light of time.

At the end of the 20th century, the western intellectuals converted to spatial 
theory, which is a refutation and challenge against tradition neglecting space, what is now called the spatial turn. Julian Wolfreys comments, "an emerging interdisciplinary formation centred on the problematics of 'space', 'place' and 'cultural geography'"'. It reflected space from cultural geography and urban sociology to philosophy, influencing contemporary western social life, culture and intellectual. Among them, The Production of Space (1974) by Henri Lefebvre and Texts/Contexts of Other Spaces (1984) by Michel Foucault established a theory basis. Henri Lefebvre states that space has been playing a more and more important role in the modern society. Henri Lefebvre holds that modernity is a hinge between time and space, the reason why capitalism becomes corrupted, but not dead, is that the unlimited expansionary and self-breakthrough of space in capitalist mode of production. Lefebvre's urban spatial theory states that "urban phenomenon and urban space are not only a projection of social relationships but also a terrain on which various strategies clash" [2]. He defines urban space as "the place where people walk around, find themselves standing before and inside piles of objects, experience the intertwining threads of their activities until they become unrecognizable, entangle situations", and the "urban space is concrete contradiction" (ibid). Foucault claims that we have been in the epoch of space, "In any case, I believe that the anxiety of today fundamentally concerns space, no doubt much more than time. Time probably appears only as one of the various possible operations of distribution between the elements that are spread out in space" [3]. Foucault divides the history of space into three periods: the hierarchical space of the Middle Ages and the space of Cartesian extension in early modernity, the third stage is the "space of emplacement" ${ }^{\text {"2 }}$ but his theory is characterized by the spatialization of power and knowledge, which is supported later by Lefebvre, "This is why urban space is so fascinating: centrality is always possible. At the same time, space can empty itself, expel its content, become a place of pure scarcity and power." ${ }^{3}$ David Harvey argues, "Capitalism produces its own geography" (5), and he thinks that the essence of urban space go through a process of constant change, development and deepening. In the early stage, people take the urban space as the physical and natural entities comprised of roads, houses, public facilities. In modern time, people's understanding of urban space is developed and expanded. Therefore, the urban space not only consists of material space, but social space composed of country, government, court, police and other management institutions. Through the study of Los Angels, Edward Soja puts forward his theory of postmodern geography. According to his explanation, urban space refers to the spatiality of city life, more exactly, "cityspace refers to the city as a historical-social-spatial phenomenon, but with its intrinsic ${ }^{1}$ Julian Wolfreys, Introducing Criticism at the 21 st Century(Edinburgh: Edinburgh University Press, 2002) 180.

${ }^{2}$ Michel Foucault, Of Other Space [A] Michiel Dehaene \& Lieven De Cauter, eds. Heterotopia and the City: Public Space in a Postcivil Society. (London \& New York; Routledge, 2008) 14. This text, entitled "Des espaces autres" was a lecture given by Michel Foucault on 14 March 1967 to the Cercle d'études architecturales (Circle of Architectural Studies).

${ }^{3}$ Henri Lefebvre, The Urban Revolution. (Minneapolis: University of Minnesota Press, 2003) 130. 
spatiality highlighted for interpretive and explanatory purposes" [4].

In The Production of Space, Henri Lefevre introduces a conceptual triad of space: spatial practice, representations of space and representational spaces, which is the triad of space of the perceived, the conceived, and the lived. Enlightened by Lefevre, Soja puts forward his triad dialectics of space: the Firstspace, the Secondspace and the Thirdspace. What is the Thirdspace? Soja explains that, "The central argument of Thirdspace was that there is another way of thinking about the social production of human spatiality that incorporates both Firstspace and Secondspace perspectives while at the same time opening up the scope and complexity of the geographical or spatial imagination."(ibid) From what Soja described as a Firstspace perspective (Lefebvre called it perceived space), cityspace can be studied "as a set of materialized 'spatial practices"' that work together to produce and reproduce the concrete forms and specific patterns of urbanism as a way of life. Here "cityspace is physically and empirically perceived as form and process, as measurable and mappable configurations and practices of urban life." From what Soja depicted as a Secondspace perspective, "city space becomes more of a mental or ideational field, conceptualized in imagery, reflexive thought, and symbolic representation, a conceived space of the imagination"(ibid), or what he describes as the urban imaginary. Soja makes a summary that Firstspace perspectives are more objectively focused and emphasize "things in space," while Secondspace perspectives tend to be more subjective and concerned with "thoughts about space." In the alternative or "third" perspective, the spatial specificity of urbanism is investigated as "fully lived space, a simultaneously real-and-imagined, actual-and-virtual", locus of structured individual and collective experience and agency. Thus, Soja makes the study of urban space with infinite complexity and diversity.

\section{The Mutual Construction between City and Literary Texts}

The questions of what a city is and how cities are represented in literary works have occupied the attention of many scholars. Indeed, one of the paradoxes of studying cities in literary works is that how the city is to be defined has proved as problematic as has the question of how they should be literarily studied. Considering two views of the city, one by Lewis Mumford, who has been called America's last great public intellectual, in his classic book The Culture of Cities, the other by Raymond Williams (1973) in The Country and the City. To Lewis Mumford:

The city, as one finds it in history, is the point of maximum concentration for the power and culture of a community. It is the place where the diffused rays of many separate beams of life fall into focus, with gains in social effectiveneess and significance. The city is the form and symbol of an integrated social relationship; it is the seat of the temple, the market, the hall of justice, the academy of learning. Here in the city the goods of civilization are multiplied and manifolded; here is where human experience is transformed into viable signs, symbols of 
conduct, system of order" [5]. The defining features of the city focus on its strategic functioning to "a community", its significance as civilization energy besides its part in facilitating the market. Such a description of how the city is to be comprehended contrasts with the depiction provided by Raymond Williams:

The great buildings of civilization, the meeting places, the libraries and the theatres and domes; and often more moving than these, the houses, the streets, the press and excitement of so many people with so many purposes. I have stood in so many cities and felt this pulse: in the physical differences of Stockholm, and Florence, Paris and Milan [6].

Both Mumford and Williams are concerned to identify the city as an emblem of civilization and culture. What is the distinction is that Mumford conveys the significance of the city in functional terms, Williams give priority to experience. Cities are multifaceted, no one of which should be privileged as constituting the defining elements of it.

Before bringing us to his narrative labyrinth, Roland Barthes tells us there are "Different Realisms" rather than "Sole Realism", and each fiction creates its own realistic word. If that really holds water, the images of cities in the texts would be a bigger part of narrative realism. Accordingly, how the representation of urban writing is expressed? From pre-modernism to modernism, and postmodernism, each narrative mode provides us with different views on reality, which including different views on urban. From Daniel Defoe and Charles Dickens to Joseph Conrad and T.S. Eliot, followed by Ralph Ellison and Thomas Pynchon, each writer reads urban in their own way which indicates how they read text. In literature of pre-modernism, the "industrial capitalist city", argues Edward W. Soja following Iain Chambers, has been "with its decidedly fixed referents and established urban epistemologies" [4]. However, in the modernist literature, urban space is turned into a preferred symbol of the accidental nature of modern experience. As Raymond Williams suggests, high modernist explore the symbolic power of the image of the fragmented, isolating urban spaces with haunted, silent crowds [7]. Subsequently, the postmodern turns to an ontological concern from an epistemological one, "from problems of knowing to problems of modes of being" [8]. In postmodern literature, the city is often depicted as indeterminate and unstable, as Peter Middleton and Tim Woods argues, the urban space is imagined as "constantly fluctuating, constantly under negotiation, always decentralised and structured by altering simulations" [9]. Thus, when literary works gives urban imaginative reality, and in turn the urban changes promotes the turn of literary texts. It is the textuality that is taken as the constant mutual construction between urban and fiction.

Mike Crang, in Cultural Geography, argues that literary works not only simply reflect the outside world. It is misleading that attention is only paid to depiction of the world, which misses the most effective and interesting elements in literary geographical landscape. Literary works not only simply describe the geographical landscape with emotion, but offer the different way to know the world. 
Literature is not the mirror to reflect the world any more, literary space is not the imitation or representation of time in certain space any more. The literary space comes from reality space, what's more, literature itself becomes the important part of construction of social reality space.

"If the City is a text," Joyce Carol Oates asks, "how shall we read it?" [10] Urban analysis has become a diversified body of knowledge including a wide range of disciplines, including geography, planning, culture, economics, etc. However, one of the immediate problems is that what might be defined as the urban writing in literary field, which has misty lines and lacks any uniform consensus as to its definition, just as the definition of what constitutes a city. There will be no consensus on the constitution of the city as there will be no agreement on how the city should be written in literature. We can no more expect consensus on the definition of what constitutes the city as we could expect critics to agree on how the city should, and could, be represented in literary works. Although the nature of the city is complex, urban studies is diversified, it is not to imply that there is no identifiable core as to what should constitute urban writing. Such a core would center around the understanding of the spatial, social and cultural connotation of the city.

\section{Representation: The Remaking of Urban Space}

Under the influence of history-centered narration, literary study has inclined to focus on time dimension, underestimating space dimension, diachronic analysis as historicity, temporality, eventuality became the dominant modes of literary criticism. As far as the writer is concerned, the writer's life story, literary creation process and the evolution of writing style had been emphasized; as far as the text is concerned, attention had been given to the development of plots, the shape of full character and narrative time; as far as the basic theory is concerned, the priority had been given to the origin of literature, the law of literary development and the literary trends. In literary study, time dimension had been strengthened, space dimension had been underestimated. Literature and space had been far reach of literary theory. With the spatial turn, literary analysis has been changed by the spatialization of literary theory in a different way.

In The Production of Space, one of the trialectics of spatiality by Henri Lefebvre is representations of space, he defines that "Representations of space, which are tied to the relations of production and to the 'order' which those relations impose, and hence to knowledge, to signs, to codes, and to 'frontal' relations" [11]. According to Stuart Hall, "representation connects meaning and language to culture", "representation means using language to say something meaningful about, or to represent, the world meaningfully, to other people... Representation is an essential part of the process by which meaning is produced and exchanged between members of a culture. It does involve the use of language, of signs and images, which stand for or represent things." [12] To put it briefly, representation is the production of meaning through language. The Shorter Oxford English Dictionary suggests two relevant meanings for the word: the first is to represent 
something, to describe or depict it, to call it up in the mind by description or portrayal or imagination; to place a likeness of it before us in our mind or in the senses; the second is to represent and to symbolize, stand for, to be a specimen of, or to substitute for. Actually, Lefebvre takes the representations of space as the conceived space, "the space of scientists, planners, urbanists, technocratic subdividers, as of a certain type of artist with a scientific bent-all of whom identify what is lived and what is perceived with what is conceived" [11]. Lefebvre thinks that representations of space are the dominant space in any society, a storehouse of epistemological power, "This conceived space tends, with certain exceptions 'towards a system of verbal (and therefore intellectually worked out) signs,' again referring to language, discourse, texts, logos: the written and spoken word." (ibid) Corresponding to Lefebvre, Soja takes representations of space by Lefebvre as Secondspace, because they are mental spaces, which consists of "dominating" spaces of regulatory and "ruly" discourse, "these mental spaces are thus the representations of power and ideology, of control and surveillance." (ibid) as well as "the primary space of utopian thought and vision, of the semiotician or decoder, and of the purely creative imagination of some artists and poets." (ibid)

One of the most typical way of cultural representation of urban Space is to focus on textual representations rather than other cultural forms, music, art or film, because literary texts not only reveal the writer's reflections on urban space, but show the character's experience in urban space. Therefore, the textual representations offer unique way to know the city. There are many critics who made great contribution to the writing of the representations of space, like Maurice Blanchot, Gaston Bachelard, Fredric Jameson, Mike Crang and Foucault, etc. In The Space of Literature, Blanchot analyzes Mallarmé's experience and space, Kafka and space of death and Rilke from the perspective of space theory, pointing out what the writing is, what literature is, and what the space of literature is; Gaston Bachelard thinks that space is the dwelling place full of human's consciousness, rather than empty container, architecture is the poetic dwelling. In The Poetics of Space, architecture is reflected and imagined uniquely from the method of phenomenology and symbolism; Fredric Jameson maps the production of contemporary literature and art in Postmodernism, or, The Cultural Logic of Late Capitalism. In Cultural Geography by Mike Crang, literary landscapes: writing and geography is discussed in detail, Crang points out that the heterogeneous coexistence of the space of literature and reality space make the spectacle in literary texts endowed with new significance; Edward Soja considers that "it is now space more than time that hides things from us, that the demystification of spatiality and its veiled instrumentality of power is the key to making practical, and theoretical sense of the contemporary era" [13].

\section{Conclusion}

All in all, on the one hand, literature study from different perspectives is involved in the spatial turn in contemporary western academic. Theorists, besides 
literary critics, more or less, illustrate their points with literature and arts; on the other hand, contemporary literary study is one important part of spatial theories, as Raymond Williams's analysis of the cultural space of city, country and metropolis based on cultural transformation; Edward Said's comprehensive anatomy of elements in literature and culture, including races, the marginal; Mikhail Bakhtin's study of exchange between different literary space with the theory of polyphony. Their studies, more or less, are all concerned about space. The interaction marks the different trend of literary study.

\section{Fund}

This paper is a part of project PXY-BSQD-2018019, and sponsored by Pingdingshan University.

\section{Conflicts of Interest}

The authors declare no conflicts of interest regarding the publication of this paper.

\section{References}

[1] Cassirer, E. (1994) An Essay on Man. Yale University Press, New Haven.

[2] Lefebvre, H. (2003) The Urban Revolution. Bononno, R. (Trans.), University of Minnesota Press, Minneapolis.

[3] Foucault, M. (2008) Of Other Space. In: Dehaene, M. and De Cauter, L., Eds., Heterotopia and the City. Public Space in a Postcivil Society, Routledge, London \& New York, 13.

[4] Soja, E.W. (2000) Postmetropolis: Critical Studies of Cities and Regions. Blackwell Publishers, Oxford.

[5] Mumford, L. (1938) The Culture of Cities. Harcourt, Brace and Company, New York.

[6] Williams, R. (1973) The Country and the City. Oxford University Press, Oxford.

[7] Timms, E. (1985) The Metropolis and the Emergence of Modernism. In: Kelley, D., Ed., Unreal City: Urban Experience in Modern European Literature and Art, St. Martin's, New York, 13-24.

[8] McHale, B. (1989) Postmodernist Fiction. Routledge, London.

[9] Middleton, P. and Woods, T. (2000) Literatures of Memory: History, Time, and Space in Postwar Writing. Manchester UP, Manchester.

[10] Oates, J.C. (1981) Imaginary Cities: America. In: Jaye, M.C. and Watts, A.C., Eds., Literature and the Urban Experience: Essays on the City and Literature, Rutgers UP, New Brunswick.

[11] Lefebvre, H. (1991) The Production of Space. Nicholson, D. (Trans.). Massachusetts Basil Blackwell Ltd., Cambridge.

[12] Hall, S. (1997) Representation: Cultural Representations and Signifying Practices. Sage Publications, London.

[13] Soja, E.W. (1989) Postmodern Geographies: The Reassertion of Space in Critical Social Theory. Verso, London. 